\title{
ACRL honors the 2008 award winners A recognition of professional achievement
}

\section{ACRL Excellence in Academic Libraries winners announced}

This year's recipients of the Excellence in Academic Libraries Award are the Shatford Library at Pasadena City College, Pasadena, California; the Laurence McKinley Gould Library at Carleton College, Northfield, Minnesota; and the McMaster University Libraries, Hamilton, Ontario. Sponsored by ACRL and Blackwell's Book Services, the award recognizes the staff of a college, university, and community college library for programs that deliver exemplary services and resources to further the educational mission of the institution.

"Receiving an Excellence in Academic Libraries Award is a national tribute to a library and its staff for the outstanding services, programs, and leadership they provide to their students, administrators, faculty, and community," said Mary Ellen K. Davis, ACRL executive director.

\section{Shatford Library}

The Shatford Library at Pasadena City College, winner of the community college category, was recognized for continually working to enhance students' experiences at the library.

"Innovative is the best word to describe why Shatford Library won this award. They excel in their information competency work; and they provide new technologies to advance the academic success of Pasadena Community College students," said Camila Alire, chair of the 2008 Excellence in Academic Libraries Selection Committee and dean emerita, University of New Mexico and Colorado State University.

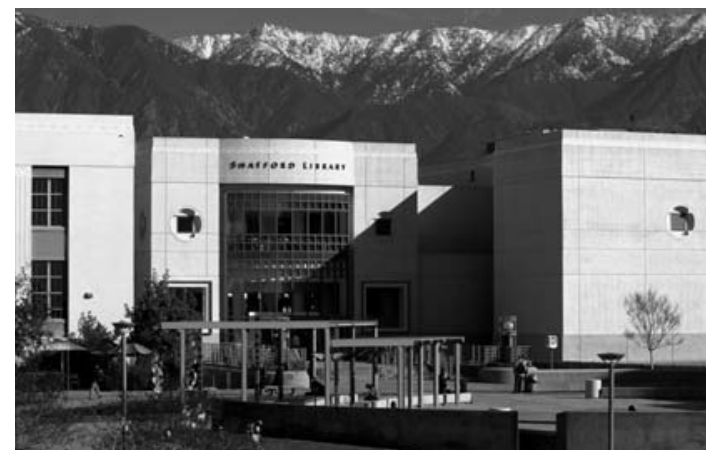

Pasadena City College's Shatford Library.

"Pasadena City College's Shatford Library is honored to have been chosen for the 2008 Excellence in Academic Libraries Award," said Mary Ann Laun, assistant dean at Shatford Library.

"This award celebrates the collaborative work of our library faculty and staff in the delivery of quality instructional programs, resources, and services to the college's 30,000 students and to our community. It also recognizes the commitment to planning and evaluation of services that directly support the college's motto, "Student Success, Our Top Priority."'

\section{Laurence McKinley Gould Library}

The Laurence McKinley Gould Library at Carleton College, winner of the college category, impressed the selection committee with its use of technology in the library.

"The Gould Library at Carleton College was recognized for working hard in a team atmosphere in order to provide a welcoming environment for its students and faculty

Megan Griffin is ACRL program coordinator, e-mail: mgriffin@ala.org 


\section{Hernon named Academic/Research Librarian of the Year}

Peter Hernon, professor in the Graduate School of Library and Information Science at Simmons College, is the 2008 ACRL Academic/Research Librarian of the Year. The award, sponsored by YBP Library Services, recognizes an outstanding member of the library profession who has made a significant national or international contribution to academic/research librarianship and library development.

Hernon will receive a $\$ 5,000$ award on Monday, June 30, at the ACRL President's Program at the ALA Annual Conference in Anaheim.

"Dr. Peter Hernon was selected because of his substantive body of research over a career of more than 30 years. His research, publications and presentations significantly impact the library profession," said award committee Chair Cynthia Steinhoff.

“Dr. Hernon's work, which focuses on such varied topics as

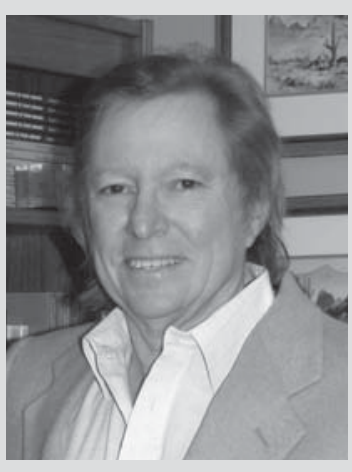

Peter Hernon presentations in the areas of customer service and assessment have assisted many academic libraries in improving the quality of their user relationships.

He has published extensively on such topics as library leadership, government information issues, and service quality. His 1998 book Assessing service quality: Satisfying the expectations of library customers was the unanimous winner of the Highsmith Library Literature Award for its outstanding contribution to the body of library literature. A 2007 survey published in College $E$ Research Librarassessment, government information, service quality and leadership, addresses very real issues and questions that academic librarians face every day.'

"I am humbled by the receipt of this prestigious award and recognition of the body of research and other scholarly writings that I have produced since 1972," said Hernon.

"I continue to conduct research, as there is so much that I still want to continue to learn. As someone who has spent almost his entire career in the profession serving as an LIS educator, this award takes on added significance to me. It reflects that the so-called divide between those in practice and those of us in education need not be great. I appreciate recognition of my scholarship for its contribution both to theory and practice. I enjoy working with library directors and other staff and believe that the award is confirmation of my continued close association with practice."

Hernon has a distinguished record of service to the profession. His research and ies listed Hernon as the fifth most cited author in LIS journals from 1994 to 2004. Hernon's writings have been translated into several languages, including Japanese and Korean.

From 1993 to 2002, Hernon acted as editor-in-chief of the Journal of Academic Librarianship and is currently coeditor of Library $\mathcal{E}$ Information Science Research. He previously served on the editorial boards of College $\&$ Research Libraries and Publications in Librarianship, as well as the advisory committee for ALA Editions.

Hernon served on the faculty at Simmons from 1978 through 1983 and returned in 1986 after a stint at the University of Arizona. His major teaching interests include government information, including information policy; the role of research; reflective inquiry, research design, and research methods; evaluation of library services; and academic libraries.

He has also acted as a visiting professor in the library and information studies programs at Victoria University in Wellington, New Zealand; University of Arizona-Tucson; and University of Wisconsin-Madison.

Currently, he serves as lead professor at Simmons College for the newly created Ph.D. program, Managerial Leadership in the Information Professions, which began in 2005 with a multi-year grant from the Institute of Museum and Library Services. 


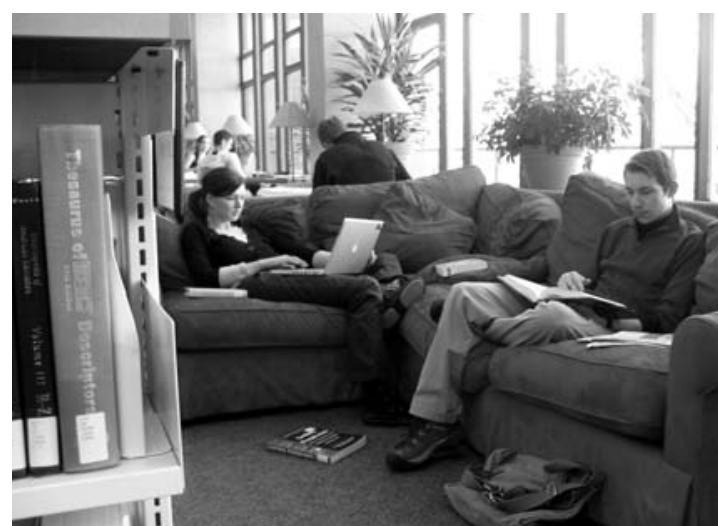

Students at the Gould Library at Carleton College.

by utilizing technology to enhance space, services, and resources," said Alire.

"To us, this award is all about esprit de corps within the library, and partnerships in the college community and beyond," said Samuel Demas, college librarian at Carleton College. "The Gould library staff works hard to nurture a culture of creative collaboration, and every day they model the teamwork that underlies superb service. It is a thrill for us to receive this validation of our values and of our efforts to serve the Carleton community."

\section{McMaster University Libraries}

The McMaster University Libraries, winner of the university category, was selected for its focus on user-centered innovations and services.

"McMaster University Libraries exemplifies a successful transformation from a traditional research library to an innovative, user-centered library using technological advances to accomplish its goals," said Alire.

"Receiving this international recognition stands as tribute to the hard work and dedication of the staff here at the McMaster University Libraries," said Jeffrey Trzeciak, university librarian at McMaster University. "Its commitment to excellence and innovation is evident in all it does to advance the mission of the university. By winning this award, we can proudly say to our faculty, students, and the entire campus community that you have - and deserve-the very best!"

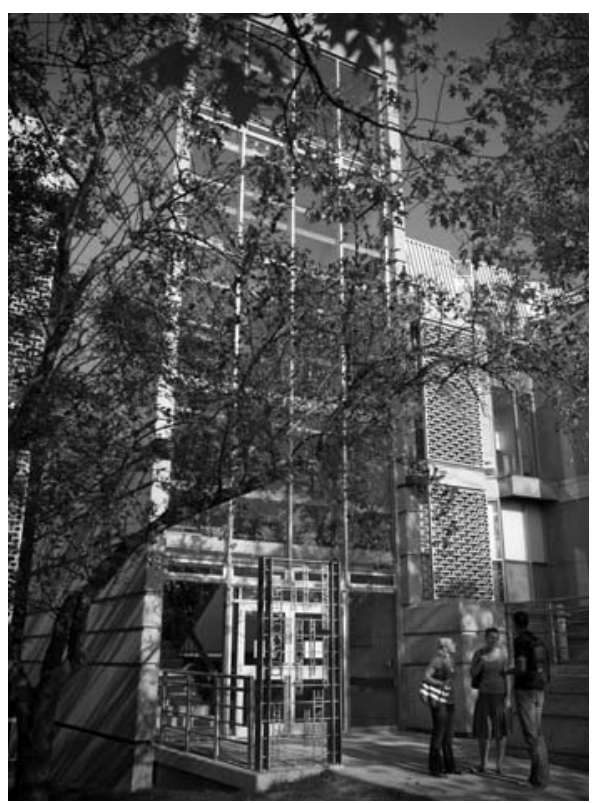

McMaster University Libraries.

Each winning library will receive $\$ 3,000$ and a plaque, to be presented at an award ceremony held on each recipient's campus. The winners also will receive special recognition at the ACRL President's Program during the ALA Annual Conference, in Anaheim, California, at 1:30 p.m., Monday, June 30, 2008.

\section{Situ and Jiang win Samuel Lazerow Fellowship}

Ping Situ, of the University of Arizona, and Shuyong Jiang, of the University of Illinois Urbana-Champaign, have been selected to receive the Samuel Lazerow Fellowship for Research in Technical Services or Acquisitions. Situ and Jiang were selected for the award for their research project on vendor-provided records and the experience of a research library in outsourcing cataloging service for its Chinese-language

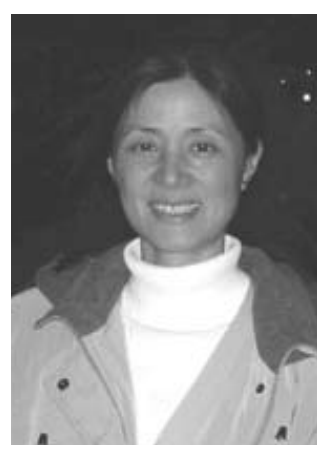

Ping Situ materials, including its backlogs.

Sponsored by Thomson Scientific, the award fosters advances in collection development and technical services by providing fellowships to librarians for travel or writing in those fields. 
"Technical processing in academic and research libraries is experiencing drastic change," said Richard Bradberry, chair of the

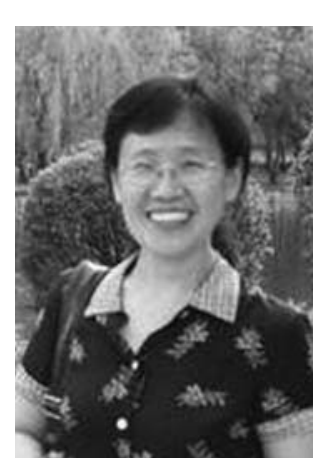

Shuyong Jiang selection committee and dean of the university library and media services at Bowie State University. "The committee felt that this proposal will have a significant and major impact on the way libraries use bibliographic data, provided by vendors, to keep current with acquisitions and cataloging; or to reduce backlogs and provide better access to collections acquired."

The library involved in this project has been outsourcing Chinese and Japanese books to a vendor and has been using Chinese book vendors for acquisitions. This experience will provide a starting point for the project in terms of issues and concerns that need to be addressed. This will also be complemented with a study conducted by one of the recipients in August 2006 on the brief records of the China International Book Trading Company (CIBTC), which calls for more focused research on Chinese book vendor records.

The award of $\$ 1,000$ and a plaque will be presented on Monday, June 30, at 1:30 p.m., during the ACRL President's Program.

\section{Gibson wins ACRL/IS Miriam Dudley Instruction Librarian Award}

Craig Gibson (associate university librarian for research, instructional and outreach services at George Mason University) is the winner of the Instruction Section's (IS) Miriam Dudley Instruction Librarian Award. The award honors Miriam Dudley, whose efforts in the field of information literacy led to the formation of the ACRL Instruction Section. The honor recognizes a librarian who has made a significant contribution to the advancement of instruction in a college or research library environment.

The award is sponsored by Elsevier on behalf of its library and information science program. A check for $\$ 1,000$ and a plaque will be presented to Gibson during the IS Program at 1:30 p.m., Sunday, June 29.

"Craig Gibson is a nationally recognized leader in the profession and has significantly advanced both the scholarship and the practical understanding and implementation of information literacy," wrote Jennifer Dorner, chair of the IS Dudley award committee and head of instructional services at the University of California-Berkeley.

Gibson has authored noteworthy book articles and chapters on information literacy and related topics and most recently served as editor of Student Engagement and Information Literacy (ACRL 2006). Gibson has also been selected as the editor of ACRL Publications in Librarianship (2008-2012), a monographic series that presents thematic approaches to the leading research and scholarly thinking in librarianship.

His service to the profession includes 25 active years of membership in IS, numerous ACRL committee appointments, and an ACRL liaison role to the TLT (Teaching and Learning with Technology) Group. He served on the ACRL taskforce that drafted the "Information Literacy Competency Standards for Higher Education" and, later, as a reviewer of discipline-specific applications of those standards for two professional library associations.

For nearly 20 years Gibson has presented at conferences and workshops and has participated in panels. He is frequently invited to speak at national conferences and has served as a consultant for many college and university libraries, sharing his experience of teaching and learning practices, professional development, and best practices for liaison librarianship and liaison programs. Gibson has also contributed to the professional development of hundreds of librarians through his role as a faculty member for the ACRL Institute for Information Literacy Immersion program.

As one colleague put it, Gibson's “outstanding commitment to service, leadership, and teaching has enriched the professional lives of many colleagues." 
Gibson has been associate university librarian for research, instructional and outreach services at George Mason University since 2005. Prior to that, he was associate university librarian for public services at George Mason University (1996-2005). He served as head of the Library User Education Program at Washington State University Libraries (1988-96) and was reference/ instruction librarian at Lewis-Clark State College from 1986-88. Gibson was assistant documents librarian at the University of Texas-Arlington (1985-86) and served as a consultant for the Colorado State Library, State Publications Depository and Distribution Center in 1985.

\section{Gover named DLS Haworth Press award winner}

Harvey Gover, assistant campus librarian at Washington State University Tri-Cities,

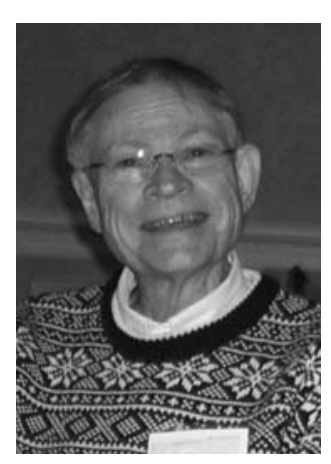

Harvey Gover has been named the 2008 recipient of the Distance Learning Section (DLS) Haworth Press Distance Learning Librarian Conference Sponsorship Award. This annual award honors an ACRL member working in the field of, or contributing to the success of, distance learning librarianship or related library service in higher education.

"Harvey Gover was selected based on his length of service to the Distance Learning Section, including chairing the section one year, his work nationally and internationally to promote distance library services and his most recent work chairing the Guidelines Committee to convert the DLS guidelines to standards," said Johanna Tunon, chair of the DLS award committee and director of distance and instructional library services at Nova Southeastern University.

Prior to becoming assistant campus librarian at Washington State University TriCities in 1998, Gover was branch campus librarian (1991-98). He served as public services librarian at Tarleton State University (1979-91).

The Haworth Press, Inc., sponsor of the award, will present the $\$ 1,200$ award and plaque during the DLS membership meeting on Monday, June 30.

\section{Collins named EBSS Distinguished Librarian}

John William Collins III, librarian of the Harvard Graduate School of Education, is the recipient of the Education and Behavioral Sciences Section (EBSS) Distinguished Education and Behavioral Sciences Librarian Award. This award honors a distinguished academic librarian who has made an outstanding contribution as an

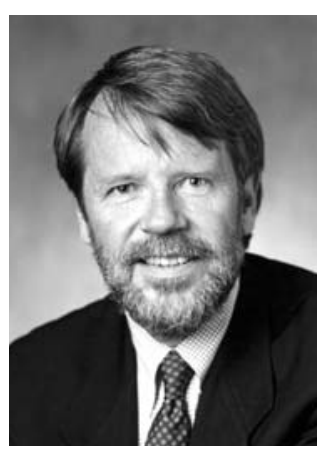

John William Collins III education and/or behavioral sciences librarian through accomplishments and service to the profession.

"Dr. John William Collins III has devoted over 30 years to librarianship and for over 20 years has been an active and contributing member of ACRL and EBSS," said Award Committee Chair Paula McMillen, social science reference librarian and associate professor at Oregon State University. "He has directly and indirectly influenced the direction of librarianship by cofounding the ACRL/Harvard Leadership Institute. He has mentored and created professional development opportunities, promoted the exploration of issues through editorial boards and his own scholarship, and advocated for a more engaged and inclusive profession."

"Beyond his years of service directly to the profession, he has kept the perspective of libraries and their users vital through key advisory roles in the development of the National Library of Education and the new ERIC database," said McMillen. "He truly epitomizes a professional lifetime of service and achievement."

Prior to working at the Harvard Graduate 
School of Education, Collins was head of the Educational Resources Library at Boston University (1982-85), where he also served as assistant head of bibliographic services at Mugar Memorial Library (1979-82).

A prize of $\$ 1,000$ and a plaque, donated by John Wiley \& Sons, Inc., will be presented to Collins at the EBSS Program at 1:30 p.m. on Saturday, June 28.

\section{Tao named Doctoral Dissertation Fellowship award winner}

Donghua Tao, graduate student at the University of Missouri-Columbia School of Information Science and Learning Technol-

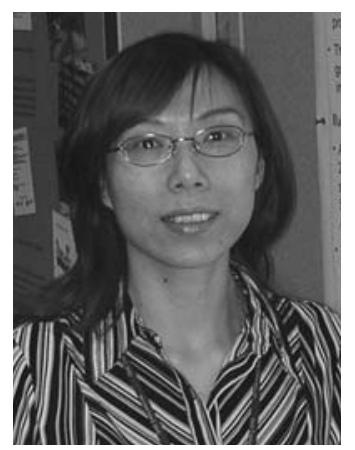

Donghua Tao ogy (SISLT), has been awarded the Doctoral Dissertation Fellowship for her proposal, "Using Theory of Reasoned Action (TRA) in Understanding Selection and Use of Information Resources: An Information Resource Selection and

Use Model." The fellowship, sponsored by Thomson Scientific, fosters research in academic librarianship by encouraging and supporting dissertation research.

The award of $\$ 1,500$ and a plaque will be presented during the ACRL President's Program at 1:30 p.m. on Monday, June 30.

"Ms. Tao's proposal is clearly significant to academic librarians, as she is looking at how students intend to use information resources in conjunction with how they actually use those resources," said Nancy H. Seamans, chair of the selection committee and associate university librarian and director of research and instructional services at the University of Iowa.

"To quote from the letter of support from her dissertation advisor and committee chair, Ms. Tao's study has the potential to provide 'needed practical guidance in library staffing and collection development, especially in questions such as how to find appropriate balance between print sources and increasingly prevalent electronic sources of information."”

\section{Norberg named Marta Lange/CQ Press Award winner}

Lisa Norberg, director of public services at the University of North Carolina-Chapel Hill (UNC-CH) Libraries, has been named the 2008 recipient of the ACRL Law and Political Science Section (LPSS) Marta Lange/CQ Press Award. The award, established in 1996 by LPSS, honors an academic or law librarian who has made distinguished contributions to bibliography and information service in law or political science.

CQ Press, sponsor of the award, will pres-

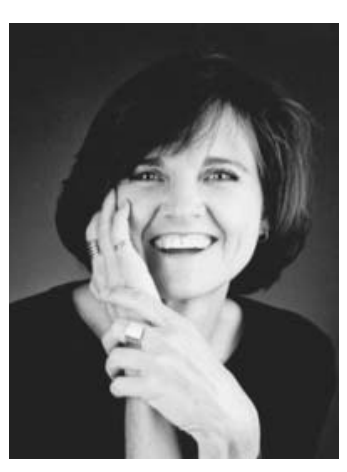

Lisa Norberg ent the \$1,000 award and plaque during the ALA Annual Conference.

Brian E. Coutts, chair of the Marta Lange Award Committee, said, "Lisa was selected in recognition of her distinguished service to ACRL as chair-elect and chair of LPSS, for outstanding research on access to government information and public presentations nationally and internationally; and for her distinguished teaching as a public affairs and government librarian and as an adjunct professor of library science."

Norberg won the Bernard M. Fry Award for Best Research article in the Journal of Government Information in 2001, and she received the Robertson Scholars Development Grant for collaborative instructional projects between the UNC and Duke in 2002. She received the Outstanding Adjunct/Instructor Teaching Award from the UNC School of Information and Library Science in 2006.

She is currently an adjunct assistant professor of practices at the UNC-CH School of Information and Library Science, a position she has held since 2003. From 2000 to 2006, Norberg was coordinator of instructional services at UNC-CH. She previously served as public affairs and government librarian at the Penn State-Harrisburg Library (1995-2000) and as public affairs liaison librarian at George Mason University (1992-95). n 